\section{BA Institute of \\ YK Business Administration \\ 六下 \\ Karachi \\ Leadership and Ideas for Tomorrow}

\section{Business Review}

Volume 3 Issue 2 July-December 2008

7-1-2008

\title{
Converged service of data, video and voice - readiness of Pakistani market
}

\author{
Syed Irfan Nabi \\ Institute of Business Administration, Karachi, Pakistan \\ Danish Abrar \\ Institute of Business Administration, Karachi, Pakistan \\ Karim Chagani \\ Institute of Business Administration, Karachi, Pakistan \\ Adnan Anwar Khan \\ Institute of Business Administration, Karachi, Pakistan \\ Anwar ul Haq \\ Institute of Business Administration, Karachi, Pakistan
}

Follow this and additional works at: https://ir.iba.edu.pk/businessreview

Part of the Communication Technology and New Media Commons

\section{(c) (;)}

This work is licensed under a Creative Commons Attribution 4.0 International License.

\section{Recommended Citation}

Nabi, S. I., Abrar, D., Chagani, K., Khan, A. A., \& ul Haq, A. (2008). Converged service of data, video and voice - readiness of Pakistani market. Business Review, 3(2), 1-20. Retrieved from https://doi.org/ 10.54784/1990-6587.1155

This article is brought to you by iRepository for open access under the Creative Commons Attribution 4.0 License and is available at https://ir.iba.edu.pk/businessreview/vol3/iss2/9. For more information, please contact irepository@iba.edu.pk. 


\title{
DISCUSSION
}

\section{Converged Service of Data, Video and Voice-Readiness of Pakistani Market}

\author{
Syed Irfan Nabi, Danish Abrar, Karim Chagani, Adnan Anwar Khan \\ Anwar ul Haq \\ Institute of Business Administration, Karachi, Pakistan
}

\begin{abstract}
This paper reports selective results of the study to explore the acceptability and readiness of consumers to switch from existing separate date, voice and video services to a single converged service over a fixed line. Providing a converged service requires effort in three areas i.e. convergence supporting technology, converged (unified) service offering and development of access devices. This study is only about a converged service offering.

Market for Cable TV service in Pakistan is more established and mature as compared to that of Internet. Research question of this study was that 'broadband alone may not be able to create a viable market for itself therefore will a converged offering of broadband and high quality cable TV be more acceptable to consumers?'. The answer is in affirmative. According to the results the acceptability of converged service in Pakistan is going to be based primarily on pricing but there may be some other needs that have to be looked into. This survey based research was conducted in March - April 2007. The survey instrument used had 26 questions. A sample of about 300 respondents was used as a stratified sample of the urban population of Karachi. Primarily the questionnaires were distributed personally by the research team and filled on the spot. Therefore the response rate was very high. A total of 257 valid responses were received. Karachi was selected because it has representation of people from all parts of the country and has a high population density with most of the people having access to data, voice and video services and can be considered as potential consumers of converged service.
\end{abstract}

Pakistan is an upcoming economy with a very high growth rate in IT sector. Thus providing a converged service of data, voice and video on a single fixed line has great potential. Results of this research can provide valuable information about consumers' preference to companies for making better-informed decisions on strategic planning and investing in converged services. It also provides a direction for further research.

Keywords: convergence, broadband, cable TV, fixed line, Pakistan 


\section{INTRODUCTION}

The term convergence literally means coming together at the same point. Technically, with reference to information technology, it is commonly used for the "synergistic combination of voice (and telephony features), data (and productivity applications) and video onto a single network" (Asian Development Bank Technical Assistance Report 2006). Although the concept of convergence is not new but until recently the three services were considered practically disparate from each other. They used dissimilar medium of communication, different end-user equipment and were regulated by separate regulators for each type of service. (Gillis and Oyedemi 2004). According to Gillis and Oyedemi (2004) "Convergence is the combination of all these different media into one operating platform. It is the merger of telecom, data processing and imaging technologies".

Convergence is defined in many ways i.e. technological, economic, geographical, political, and functional convergence (Fowler 2000). Similarly according to Robert E. Babe (1996) the Organization for Economic Co-operation and Development (OECD) has given three dimension of convergence technical, functional, and corporate. Functional convergence deals with the products and services and not the technology used to provide them (Babe, 1996, 283-84). This paper discusses the functional convergence only which is about a single provider supplying the three services to the consumer using single medium.

The paper discusses the reasons that are creating demand for convergence by elaborating upon factors affecting the Internet growth and the cable TV market. The results of the research are discussed along with the factors that are providing growing trend towards convergence for each type of service i.e. Internet for data, TV for video and telephony for voice. Further, consumer views and preferences are analyzed in context of the drivers or impediments of convergence, its growth, and penetration for Pakistan's urban consumers derived from the research conducted by Fowler in 2005. Conclusion and recommendations for further research are given at the end.

\section{RESEARCH METHODOLOGY}

This is a survey based research. The survey was conducted in March - April 2007. The survey instrument used for the research was based on the literature review and went through numerous revisions to ensure validity and reliability. A sample of about 300 respondents was used as a stratified sample of the urban population of Karachi. Primarily the questionnaires were distributed personally by the research team and filled on the spot. Therefore the response rate was very high. Some were sent out as well. A total of 257 valid responses were received. Karachi was selected 
because it has representation of people from all parts of the country and has a high population density with most of the people having access to data, voice and video services and can be considered as potential consumers of converged service. Another important aspect of selecting Karachi was that it has a converged service provider as well. The survey involved filling up a questionnaire consisting of 26 questions. The results were tabulated in Microsoft Excel and analyzed using SPSS. Selected results are reported through this paper. The graphs show the response of all the respondents including those that did not answer a specific question. But the percentages quoted are calculated on the basis of the respondents that answered the specific question ignoring those that did not answer the specific question that was being analyzed.

\section{THE GROWING TREND OF CONVERGENCE}

In telecommunications Convergence is the phenomenon of combination of data, voice and video services. In today's digital world all these three types of services once digitized becomes digital data and in their most basic form consists of binary digits. The transmission of any of the above three type of services can be simply referred to as 'data transmission' and theoretically can be handled by any data transmission service provider. Since there are different requirements of data integrity, availability and transmission delay practically all the three have to be treated differently. Traditionally these three services are provided by three different types of service providers and three different types of end-user equipment are needed to use the services. The end-user equipment for data is computers, for voice it is telephone sets and for video it is TV sets. Further, the data services are provided through the Internet by Internet Service Providers (ISPs), voice services through telephony by telecom operators and video through terrestrial and satellite wireless broadcasts and cable network by TV broadcasters. There are various factors affecting convergence. To get a holistic view of the factors affecting the convergence, factors affecting each of the three services are discussed separately. The factors that affect the demand, usage and growth of Internet, Cable TV and telephony are looked at first and subsequently the drivers that are specific for convergence are analyzed in the next section.

\subsection{INTERNET}

Internet is considered a driver for growth and competitive edge for nations (Lee \& Chan-Olmsted 2003). However, its effective deployment and usage depends on many factors. These are demographics, infrastructure and demand. Demographic factors include a country's literacy rate, media consumption habits, years of education, the demand for information and the need to be online. The infrastructure factors are bandwidth, price and the quality of service. The most important is demand of Internet. There are some important factors of demand and growth of Internet. Five of these are discussed below in light of consumer preferences. 


\subsubsection{THE GROWING DEPENDENCE ON ONLINE DATA \& TRANSACTION}

Globally the availability and the need of data have increased tremendously. As people from geographically disperse land use 'information superhighway' to move to global village in the digital space, data becomes the prime resource. Traditional information devices like TV and radio were a source of information as well as entertainment. Still they are to some extent but now Internet has overtaken them and has become the prime source for information and to some extent of entertainment as well. The Internet has shown tremendous growth with more than quarter of a billion users added by the developing world (World Bank 2007). There has been only 5\% growth of TV sets in South Asia as compared to a $14 \%$ growth rate of Internet (World Bank 2007). The e-business, which saw a decline at the turn of the century, is once again booming. Online advertising, e-purchasing and e-banking are now common. E-governance, telemedicine and e-learning all have gained momentum.

Although there has been increase in economic activity due to Internet in the World and in Asia but Pakistan is lagging behind. The Economist Intelligence Unit (EIU) 2007 e-readiness value for North America was 8.58 as compared to 6.10 for Asia-Pacific which is not bad. Pakistan on the other hand was at 3.79 and ranked 63 amongst 69 countries surveyed by EIU. So there is a lot to catch-up with. The encouraging fact is that during 2006-2007 Asia-Pacific showed an increase of 5.79\% (up 0.33 points from 5.77 in 2006) Pakistan increased by $75 \%$ (up 0.76 points from 3.03 in 2006) showing a very promising increase compared to Asia-Pacific region (Economist Intelligence Unit 2007). The Internet population in Pakistan is very low at 1.7 per 100 inhabitants (Business Monitor International 2006). Although there are 10.5 million Internet users and the adult literacy rate is 58\% (CIA 2006), yet, not only the growth of Internet in Pakistan has been slow but majority of the Internet users do not use Internet daily. With the Internet access available as a value added service over the mobile cellular network it is hoped that the frequency of Internet usage might also increase if bigger screen/keyboard, better speed, lower cost and more ease of use were available (Nabi et al. 2007).

More than $95 \%$ of Pakistani Internet users either use Cable Net or Dialup Internet access (PTA 2006). The speed provided by a Dialup or a Cable Net connection is slow for efficient use of the Internet for high-end applications. Applications like video conferencing and file sharing that are part of distance learning and etransactions are cumbersome to use with cable net or dialup connections. Similarly multiplayer gaming over the Internet requiring high bandwidth is also not possible. The latest development in high-end applications means that there would be a need for an even larger bandwidth Internet service in future. However, as shown in 
Figure $\mathbf{- 1}$ more than $50 \%$ of the Internet users that responded to the question were satisfied with the current level of Internet service.

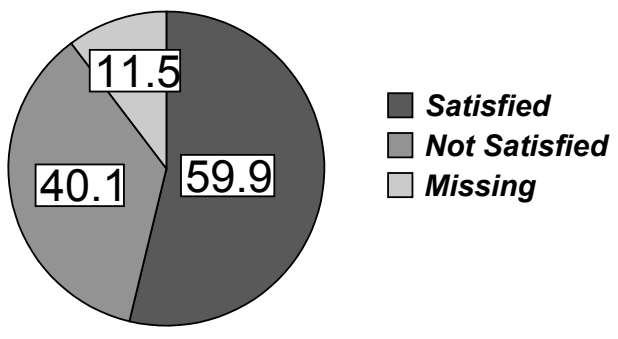

Response to the question: Are you satisfied with your Internet service at home?

Figure 1: Satisfaction with current Internet service at home

This could be one of the reasons why broadband Internet has not clicked in Pakistan at the fist instance i.e. the users are satisfied with whatever bandwidth they are getting and perhaps most of them do not need higher bandwidth since they are not utilizing the Internet fully.

\subsubsection{SOCIAL PERSPECTIVE}

Internet is one way of socializing with others. Youth, who command the greatest share of the online users, when surveyed about "what they do online", more than $50 \%$ replied in favor of online chat ('China Internet Survey Report' 2005). Thus, it is a great means of developing the global village. It is economical and unhindered by geographic, racial or ethnic barriers. According to the survey results chatting is one of the major uses of Internet in Pakistan as well.

\subsubsection{DEMAND FOR IMPROVED QUALITY OF SERVICE (QOS)}

One attribute of the QoS of Internet connection that appeals most to the consumers is Speed. Although the Internet consumers in Pakistan may not be using applications that require high bandwidth but most consumers strongly believe that data transfer speed is the most important factor for any Internet service. As shown by the results of this survey. Consumers were asked to rank the most important attribute of Internet service among price, speed, connectivity, or others. Almost $91 \%$ responded that speed is the most important aspect of an Internet service. In Figure -2 the ranking of speed on a scale of 1-4 is shown. It can be seen that for more than $90 \%$ of the respondents speed is the most important characteristic of an Internet connection. 


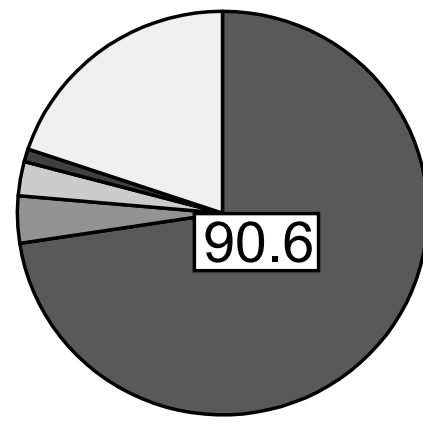

Figure 2: Rank of Speed as the most important factor of Internet connection

\subsubsection{LITERACY RATE \& EDUCATION LEVEL}

Internet and its services can be better utilized when the users are literate. "You would not expect a country like Nepal or Pakistan to reach the kind of Internet penetration rate enjoyed by Singapore or Japan, when the majority of their adult population is illiterate." (Xiaoming and Kay 2004). But it is not only literacy. Vehovar et al (1999) are of the opinion that one of the important factors of Internet usage is language. Since most of the content for computers as well as Internet is in English, so understanding of English language becomes a critical factor for better utilization of Internet. Therefore the countries that have English as their primary language have better utilized the Internet. It was almost a decade ago when Vehovar et al emphasized the importance of English to gain advantage of Internet since English was the language of Internet. The situation has improved since then. There has been localizations and other languages are more and more being used in computers in non-English speaking countries. Low literacy rate in Pakistan with a very small percentage among them that know English accompanied by the fact that Urdu content on Internet is not much and only few websites are in Urdu or other Pakistani regional languages is a problem in better utilization of Internet. Devraj (2000) agrees with Vehovar et al. (1999) and adds that in his opinion "even literate South Asians cannot benefit from the IT revolution without a working knowledge of the English language because of poor "localization" - a highly technical process by which computer programs are translated into another language". Therefore, it may be 
said that the growth of Internet and information society in Pakistan is inhibited by the low literacy rate. This may be improved if localization of computers and Internet is done accompanied by educational institutions adopting Internet at a faster rate especially at the primary school level.

The survey results show that the years of education have a positive effect on Internet consumption. People with more years of education use Internet more often than those with fewer years of education. Considering only the respondents with more than 14 years of education (157 respondents) more than $82 \%$ of them use Internet at least once a week.

Internet, Cable TV and Telephone are not only sources of communication and entertainment but are also important sources of information and learning. Although the results show that the number of years of education has a positive impact on the preference for converged service, yet, there are other factors affecting the preference for a converged service. Figure-3 shows some interesting results. Education has some affect on the preference for a converged service. There were $67 \%$ people with 14 years or more of education among those that showed preference for converged service while $53 \%$ of the people that did not prefer a converged service also had 14 years or more of education. So the education may have some affect but not much on a preference or not for a converged service.

\section{Error!}

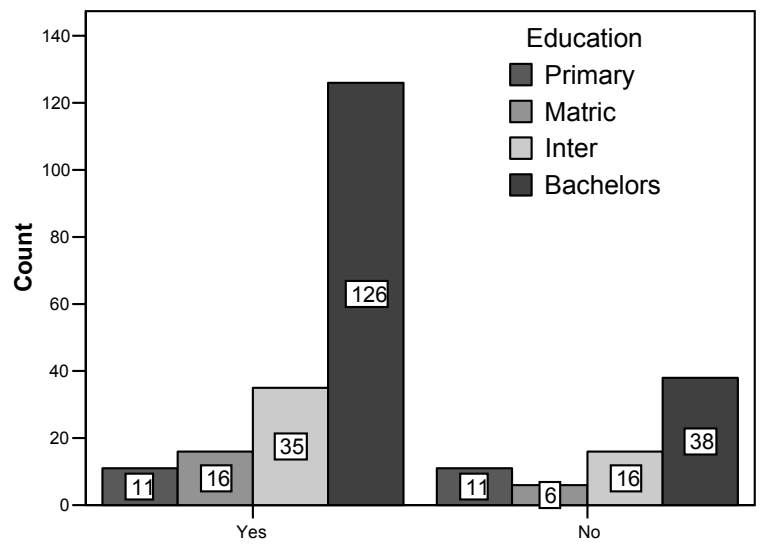

Will you prefer to have one combined service consisting of Internet, telephone and cable TV on single fixed line rather than having these three services separately?

Figure 3: Education versus preference for or against a converged service 


\subsubsection{THE INTERNET ADDICTION}

It is generally noted that the time spent on Internet increases as the number of years since first use or introduction to Internet grow and so does the dependence and the need to be online. People might initially start using Internet for a particular purpose generally to extract information or to communicate and later on expand their usage and the purpose of being on-line to various other activities. Although Pakistan lags behind in terms of education, the trend that education and Internet consumption have positive relation also hold true for Pakistan.

\subsection{TELEVISION}

$\mathrm{TV}$ is the most consumed media service at present in most countries around the world. The same holds true for Pakistan (BOI 2007).

\subsubsection{CABLE TV MARKET IN PAKISTAN}

There are more than 10 million TV homes in the country and approximately 40 million TV viewers. Cable and Satellite TV have a $42 \%$ penetration rate among urban consumers and $16 \%$ for rural consumers (Riaz, A. 2004). Therefore, the provision of Cable TV service can be a strong feature for convergence.

\subsubsection{POOR PERFORMANCE OF CABLE TV SERVICE}

Cable TV service is available in many parts of Pakistan. Even in some remote areas it is available. It is an entertainment service that is available quite cheaply. The good thing about it is that it is economical with low initial cost and very low recurring cost. With one TV set many members of a family can enjoy at one time unlike some other forms of entertainment. According to the results of this research most consumers are not satisfied with the quality of service they are receiving from their Cable TV providers. The choice of channels and programs is not up to their satisfaction. As shown in Figure- 4 more than $50 \%$ of the respondents were not satisfied with the current selection of channels available on Cable TV service. They may be bearing with is since it is cheap and there are not many cheap entertainment alternates to Cable TV service. 
Problem with Cable TV

Poor Selection of Channels available

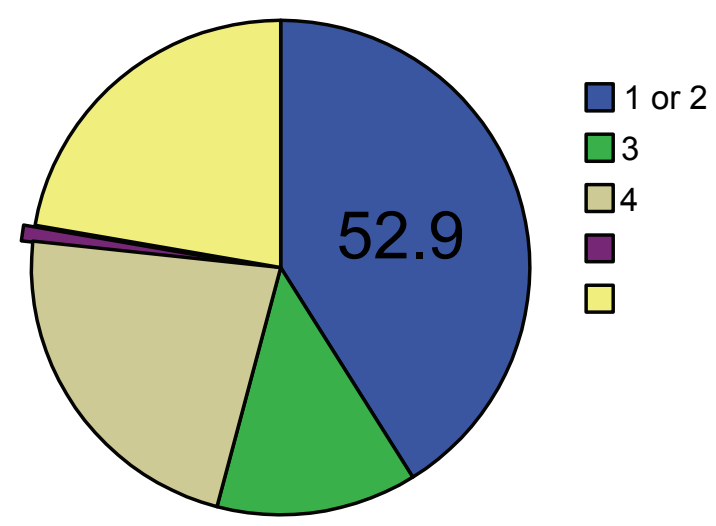

Response to the question: What is the biggest problem with your current cable TV service? Rank 1 as poorest and 4 as least poor Price, Picture, Quality, Channels available

\section{Figure 4: Rank by respondents of 'Channels available' as the biggest problem}

Therefore for converged service providers to be successful they have to offer better customized choice of channels. However, being a price conscious society the respondents rejected the idea that consumers might be willing to pay extra for a better Cable TV services. Since Cable TV is seen as a low cost entertainment affordable even for lower middle and lower classes of the society perhaps it is not desirable by them to pay more just for the quality of service. For those who are willing to pay more there are other options like using satellite TV directly via a dish antenna.

\subsubsection{CONTRASTS BETWEEN TV \& INTERNET}

As clear from the statistics cited earlier the TV market is much bigger than the nascent Internet market. The research results show that the average number of Internet users in a home for the sample is 2.93 as compared to 4.75 Cable TV viewers per home. This shows that there are more Cable TV users then Internet users. It may be taken as the existence of a much bigger Cable TV market as compared to that of the Internet. Another important aspect to remember is that a computer is need by each person that wants to use the Internet while more than one 
person can easily watch Cable TV on a single television set. Therefore the cost of a computer and the need for as many computers as the number of simultaneous users in a family is a constraint in the growth of Internet service market as compared to the growth of Cable TV service.

\subsection{TELEPHONY (VOICE)}

Two important trends for voice services are 1) that traditional telephony technologies are utilized to make voice calls and 2) that revenues generated from voice alone are now saturating (PTA 2006). The saturation point is evident in most developed economies and similar trend is likely to be observed in the developing countries as well. While the voice traffic in growing at a steady pace the data traffic growth has been much greater. (Cullen 2000). The prices of voice service are decreasing considerably. With new companies entering the market there is a pressure to reduce prices further. This has led to the transformation of business of telecom companies. They are looking for new streams of revenue by provisioning of Value Added Services to sustain growth and profitability (Cullen 2000). Although mobile companies in the world are now offering various Value Added Services (VAS) yet, the consumers see very little value in the new VAS offered by both cellular operators and fixed line operators (Berg et al. 2003). Therefore it is not easy to get premiums on VAS services.

According to this research voice services have remained stable as most people use traditional phone services to make their voice calls and telephone remains the most frequently used of the three (telephone, Internet, \& video) services. It seems that in order to entice people to a converged service the Converged Service Provider may have to market voice as a free service or as an added feature within the package offered for the converged services.

\section{DRIVERS OF CONVERGENCE}

Fowler (2005) discussed certain common drivers and impediments to the introduction of converged service as mentioned in the Figure-5. 


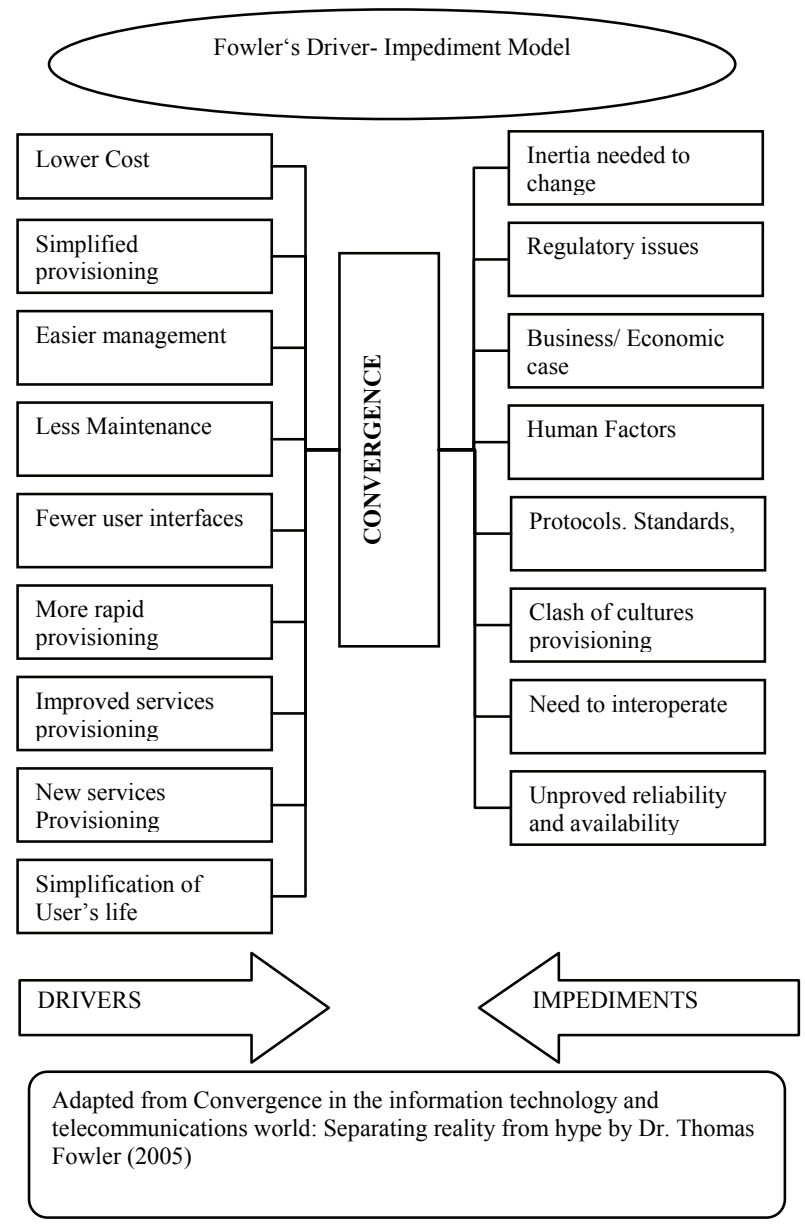

Figure 5: Fowler's Driver- Impediment Model

Some of the more pertaining ones are discussed below in reference to Pakistan and the survey conducted.

\subsection{SIMPLIFIED PROVISIONING AND EASIER MANAGEMENT}

Convergence can be accomplished with a minimum need for separate equipment. A single reception device can serve the purpose of both providing Internet service and Cable TV. The recently launched Internet Protocol Television or IPTV is a new method of delivering and viewing television programs using an IP network and high- 
speed broadband access technology. It provides three services (Cable TV, Internet and Telephone) on a single medium i.e. on existing telecommunication infrastructure. It is different from the Internet TV which is telecast through website and accessible anywhere in the world through Internet (PEMRA 2006).

A converged service can be deployed readily using the existing cable TV infrastructure. They provide a built up mesh network already deployed with wires spread across homes. This will allow the new services to be engineered and deployed without the need to add either cable or switching equipment, or modify such equipment (Minhas 2006).

The ease of selection of a converged service by consumers may also be enhanced by introducing different packages based on Internet speeds and the number of channels. As shown in Figure - 6 results of the survey indicate that nearly $73 \%$ people prefer a combined of service of cable TV, Internet and telephone instead of three separate services

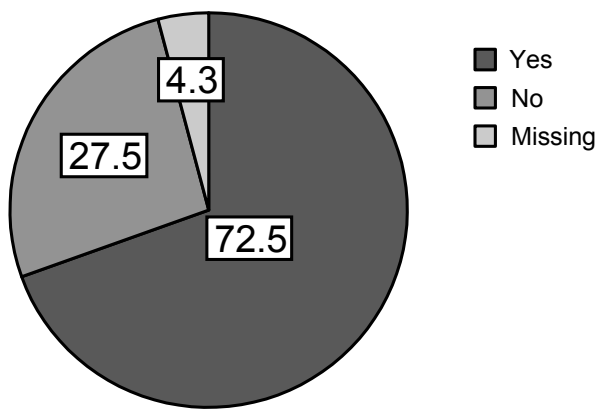

\begin{abstract}
Response to the question: Will you prefer to have one combined service consisting of Internet, telephone and cable TV on a single fixed line rather than having three services separately?
\end{abstract}

\title{
Figure 6: Willingness to use a converged service
}

\subsection{LOWER COST}

Pakistani market is a price conscious market. A low price converged service is more likely to be adopted by Pakistanis than a high priced one even if it is of higher quality. Converged service providers have to find ways to reduce their cost. Also, the government has to fulfill its resolve to encourage the spreading of an affordable "always on" Internet service by encouraging new service providers to enter the field (PTA 2004). Reduced tax rates and subsidized International bandwidth for businesses providing converged services might encourage the existing businesses to enter into this area. 
The survey conducted indicates that although $73 \%$ people preferred a converged service as shown in Figure 6, yet, only 57\% were willing to pay an extra price for the converged services as shown in Figure 7. This indicates the price sensitivity of the market.

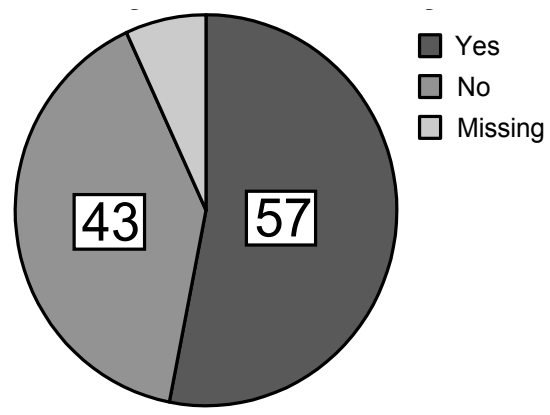

Response to the question: Will you prefer to pay extra for the converged service?

\section{Figure 7: Convergence as a premium service}

It is interesting to note that not all the $57 \%$ people who were willing to pay extra for a converged service preferred to use a converged service. Only $40 \%$ of the respondents preferred a converged service and were willing to pay extra for it. It means that price is not the only deciding factor and there are some other factors as well. Further research is need to find out more about this intrinsic need that may satisfy the consumers that are willing to pay for a converged service but do not prefer it over the existing individual services.

\subsection{FEWER USER INTERFACES AND IMPROVED SERVICES}

The converged service will require fewer separate user interfaces. A single type of plug in the wall is available which supplies raw bandwidth on demand while computers and telephones can share the same jack (Fowler 2005). Given the urban house construction boom in Pakistan, the single wire can be spread through out the house during construction. In addition, it will introduce a single billing mode thus less hassle in bill payment.

Service quality will improve when fewer components are involved in its provisioning and maintenance (Fowler 2005). Broadband connection needed for converged service means high content data interchange is possible. It will also reduce the problems related to speed that people consider as the most important problem with an Internet connection. The survey indicated that $60 \%$ of the people perceive speed as the biggest problem with their Internet connection. 


\subsection{UNIFIED REGULATIONS}

The foremost impediment in providing a converged service could be the regulation. As the converged service would bring Cable TV, Internet/data transfer, and voice over one platform new policies would be required by the regulators to allow companies to offer such service. As defined in the beginning a converged service is the combination of distinct services that are regulated by distinct regulators. With the combination (convergence) of services some of the countries have seen the merger of regulating bodies as well so that new and unified regulations be developed and employed without creating confusions or conflicting regulations. Countries like Pakistan where two different regulatory bodies exist, Pakistan Electronic Media Regulatory Authority (PEMRA) for regulating TV and Pakistan Telecommunication Authority (PTA) for telecom, a converged service offering would arise licensing and policy issues. In UK 'Ofcom' (Office of Communications) was created in 2002 to combine and streamline the regulatory functions of 5 different regulators. Similarly in 2005 in Australia the telecom and broadcast regulating bodies were merged to form Australian Communications and Media Authority (ACMA). There are number of other countries that have merged their regulators to form one organization to regulate all the issues concerning communications. We may have to follow the same example and merge PTA and PEMRA into a one independent authority. A recent example of the issues with more than one regulator regulating the same business came to light when a new mobile company launched its mobile TV service. Licensed by PTA, Pakistan's telecommunication regulatory body, the mobile company introduced the new service which was challenged by PEMRA, the regulator for broadcast \& telecast media. PEMRA viewed this as telecasting and requested PTA to stop the mobile company's TV service (Dawn 2007). There was much controversy and the solution to it is to merge the two regulatory authorities.

Another problem could be the resistance to change the infrastructure. In most middle and upper middle-income areas of Karachi, cable TV service providers are providing Internet services through 'CableNet'. It is not the same as Cable Internet where both the Cable TV and Internet signals are provided on the single co-axial cable. Instead they are running separate Ethernet cables for Internet in parallel to coaxial cables for TV signals. These providers might resist introduction of new converged service as this would result in a dual attack on their revenues (PTA 2005). It would be very important for companies introducing the converged service to price it competitively and provide better quality and high bandwidth to induce adoption.

\subsection{CONVERGENCE \& VALUE ADDED SERVICES (VAS)}

A connotation of convergence means that many services are combined. However convergence imply more than that. The technologies that support converged services also support other VAS like video on demand, more choice of channels, options for 
different speeds for Internet and variety of billing options etc. However, further research is needed to check awareness regarding these unusual/new services. Consumers can better appreciate new services if they know what these services are.

There is a difference between telecast and 'video-on-demand'. Figure 8 show the results of the awareness of one of the VAS 'video-on-demand' that might be available on a converged network.

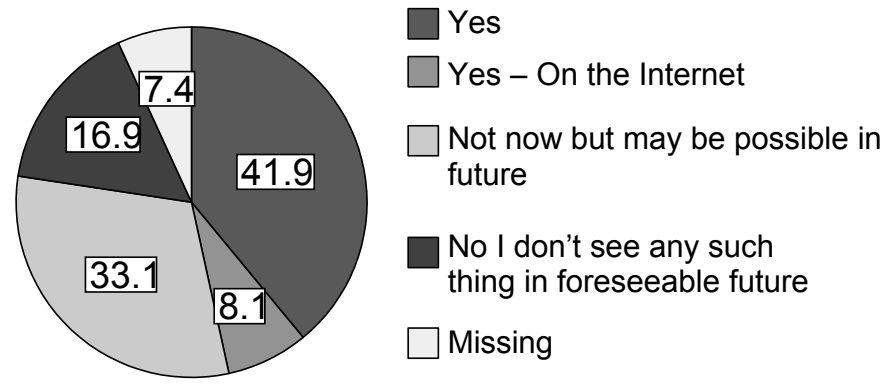

Response to the question: Can you watch the programs of your choice when you want to? Like watching 8 o'clock drama at 9:30 when you have time.

Figure: 8 Awareness of VAS

A little less than half of the respondents $(42 \%)$ seem to be unaware of the concept. They were asked if they could watch the program of their choice when they want to and $42 \%$ answered yes. It is not the right response since video-on-demand is not yet available for TV viewers in Pakistan. This may be because 'video-ondemand' service is not widely available and a new concept for them. Only WorldCall is offering downloadable video that is a step in this direction. The implication of it is that consumers/viewers need to be educated about the VAS

\section{CURRENT SITUATION IN PAKISTAN}

WorldCall Multimedia Limited, a renowned Pakistani company was the first converged service provider introducing its service in 2000. It has been successfully operating since then. WorldCall Multimedia Limited uses Hybrid Fiber Co-axial 
(HFC) network. WorldCall believes that based on the forecast that the Internet market in the country will grow, their first step is to get into the house of the consumers and revenues will follow.

The HFC network is capable of delivering interactive broadband multimedia services, including telecast video, Internet video-on-demand, pay-per-view, security services, distance learning, digital audio, telephony, video conferencing, virtual private networks, and electronic games. As copper telephone wires have limited information transmission capability, therefore to transmit large amount of information over wires, such as video signals, coaxial cables, amongst others are used. In HFC network fiber cable is used at the backend with co-axial cable at the user-end. Clifton and Defense areas of Karachi have HFC systems (Minhas 2006).

\section{CONCLUSION}

This research was conducted to explore whether the market in Pakistan is mature enough for the introduction of converged service, what are the needs of the Pakistani market and whether the required infrastructure exists for its introduction. The three services (data, voice and video) are very competitively available across the country as separate services. With mobile phone usage on the rise in Pakistan the telecom companies are frequently offering newer tariff packages to compete with each other. They are also offering VAS but emphasis is still on cutting costs. The results as discussed above indicate that although there is no real existing market for converged service but an overwhelming majority of consumers are interested in such a service with more than half of the consumers willing to pay extra for a converged service. With meticulous, targeted and aggressive marketing a real demand for converged service can be created. To enhance their revenue Cable TV providers, ISPs and telecom operators might need to collaborate with each other to exploit the social habits of majority of urban population of watching an hour or two of TV and using Internet service regularly by providing converged service over a single fixed line.

Since Pakistan is a price sensitive market therefore high quality at a high price may not entice many consumers to switch to a converged service. Rather the businesses have to provide an acceptable quality of service at a relatively low price similar to what consumers are paying for the three separate services. As discussed earlier there are some consumers interested in a converged service for reasons other than lower price alone. Their intrinsic needs have to be found and addressed in order to persuade them to switch over to a converged service.

Infrastructure is not the problem. The existing infrastructure of Cable TV may be used to provide converged service. New entrants might want to look in to deploying their own network at the same time a partnership or collaboration with existing owners of Cable TV networks might provide a more economical route into this business. As a result of this research a high level conceptual business model is being developed for better revenue generation. 
With only one converged service provider operating in Pakistan the market presents a worthwhile opportunity for other players to join in.

This was an exploratory research. Further research is needed regarding the regulatory framework for converged services in Pakistan, role of various players in promotion of converged service and the risk associated with venturing into this area.

\section{REFERENCES}

Asian Development Bank - Technical Assistance Report 2006, Preparing the South Asia Subregional Economic Cooperation Information Highway Project. November 2006, Project Number 40054.

Babe, Robert E., 1996 "Convergence and the new Technologies." In Michael Doland (ed.), The Cultural Industries. Toronto: J. Lorimer and Co., 1996, 283-307.

Berg, M., Butterfield S., Cosmas, J., Casagranda, P., Garrec, D., Guiraudou, M., Martinez, G., Launay, E., Mazieres, B., Milanesio, D., (2003) "CISMUNDUS:

Convergence Of Digital Broadcast And Mobile Telecommunications" Proceedings of the International Broadcasting Convention $12^{\text {th }}-16^{\text {th }}$ September 2003. Retrieved February 08, 2007, from http://www.broadcastpapers.com/whitepapers/paper_loader.cfm?pid=574

BOI, Board Of Investment Retrieved February 07 2007, from http://www.pakboi.gov.pk

Business Monitor International Pakistan Telecommunications Report Q4 2006 , Pg 15

China Internet Survey Report 2005 (2005). Internet Survey Chinese Academy of Social Sciences. Retrieved February 08,2007, from http://www.worldInternetproject.net/publishedarchive/China\%20Report\%202005.pd $\mathrm{f}$

CIA (2006), CIA World Fact Book 2006. Retrieved February 07 2007, from $\mathrm{http}: / /$ www.cia.gov/cia/publications/factbook

Cullen, B (2000), Convergence of voice and data telecommunications transmissions. Telecommunications Energy Conference, 2000. INTELEC. Twenty-second International, 09/10/2000 - 09/14/2000, Phoenix, AZ, USA. Retrieved February 08, 2007, from 
http://ieeexplore.ieee.org/iel5/7098/19124/00884219.pdf?tp=\&isnumber=19124\&arn umber $=884219$

Devraj, R 2000. "South Asia: Digital divide sharpens rich-poor gap," at http://www.undp.org/dpa/frontpagearchive/july00/7july00/tv070700.pdf mentioned in Xiaoming, Hao and Kay, Chow Seet, Factors affecting Internet development: An Asian survey, First Monday, volume 9, number 2 (February 2004), Retrieved June 152008 from http://firstmonday.org/issues/issue9_2/hao/index.html EIU (2007), The 2007 E readiness rankings raising the Bar. from http://www.eiu.com/site_info.asp?info_name=eiu_2007_e_readiness_rankings

Fowler, T.B. (2000). Convergence in Telecommunications: Meaning, History, Present Status, Future Rollout. Noblis, Inc. Retrieved February 07 ,2007, from http://www.noblis.org/Publications/SigmaSpring2002_2.pdf

Fowler, T.B. (2005). Convergence in the Information Technology and Telecommunications World: Separating Reality From Hype. The Telecommunication Review, 2002, Retrieved February 07 ,2007, from http://www.noblis.org/Publications/Fowler_03.pdf

Gillis, B., and Oyedemi, T.(2004). Lecture notes on Macro Environment and Telecommunications - Chapter: 3: Module 2: Global Trends in ICT/Telecoms Sector Page 29, Retrieved May 10, 2008 from http://cbdd.wsu.edu/kewlcontent/cdoutput/TR501/page29.htm.

Lee, Choongok. and Chan-Olmsted, Sylvia (2003) "Competitive Advantage of Broadband Internet: A Comparative Study Between South Korea and the United States" Paper presented at the annual meeting of the International Communication Association, Marriott Hotel, San Diego, CA, May 27, 2003. Retrieved February 08, 2007, from http://www.allacademic.com/meta/p112205_index.html

Minhas, S., (2006) Pakistan - Markets in IT \& Telecomm Convergent Technologies. Retrieved April 09,2007 , from http://www.the-south-asian.com/JulyAug2006/Pakistan_IT_Markets_convergent_technologies-PII-1.htm

Nabi, S.I., Nooruddin, M., Quratulain, Rajani, J.R., D’Souza, T.. (2007) Consumer Behavior and Cellular Industry of Pakistan, Proceeding of National Conference on Information and Communication Technologies, Bannu, NWFP-Pakistan, June 2007.

PEMRA (2006) IPTV FAQS 2006, Retrieved February 07 2007, from www.pemra.gov.pk \licensing $\backslash$ IPTV 
DAWN, the Internet Edition (2007) 'PEMRA objects to TV mobile phone service' May 04, 2007, Retrieved from http://www.dawn.com/2007/05/04/nat3.htm

PTA (2004) - Pakistan Telecommunication Authority Broadband Policy 2004 Retrieved February 07 2007, from www.pta.gov.pk

PTA (2005) - Pakistan Telecommunication Authority Consultation Paper on Broadband, 2005 Retrieved February 07 2007, from http://www.pta.gov.pk/media/broadband.zip

PTA (2006), Pakistan Telecommunication Authority Retrieved February 07 2007, from www.pta.gov.pk

Riaz, Aasiya 2004 Media and Judicial Independence in Pakistan Pakistan Institute of Legislative Development and Transparency (PILDAT), Retrieved on June 15 2008, from http://www.micci.in/pdf/MEDIA_PAKISTAN.PDF

Vehovar V., Batagelj, Z. and Lozar, K., 1999. "Language as a barrier", Retrieved June 15, 2008 from at http://www.isoc.org/inet99/proceedings/3i/3i_3.htm,

Vrdoljak, M. Vrdoljak, S.I. Skugor, G., (2000), Fixed-mobile convergence strategy: technologies and market opportunities. Communications Magazine, IEEE Feb 2000 Retrieved February 07 2007, from http://ieeexplore.ieee.org/xpl/freeabs_all.jsp?tp=\&arnumber=819904\&isnumber=177 78

World Bank annual World Development Report (2007), The World Bank Group. (2007). WDR 2007 - Questions and Answers: General. Retrieved February 08,2007, from http://go.worldbank.org/81ZUMIT5M0

Xiaoming, Hao and Kay, Chow Seet, Factors affecting Internet development: An Asian survey, First Monday, volume 9, number 2 (February 2004), Retrieved June 15, 2008 from http://firstmonday.org/issues/issue9_2/hao/index.html 
In His Harvard Business Review essay Alan Kantrow writes: "Drucker's real contribution to managerial understanding lies not so much in the utility of his ideas as in the rigorous activity of mind by which they are formulated." Drawing from history, philosophy, moral psychology, sociology, politics, science, literature and, yes, medicine - Drucker's pattern-seeking thinking models how to "identify the constellations of significance in the otherwise chaotic flow of information." His books "enact an unfolding drama of perspective." The drama stems from the openness, the unfoldingness, of his thinking-in-writing. He claims to have "never learned anything from a book" the Jane Austen "never of conversation." He has to write (or teach) to discover what thinks. Consequently, his books capture the spontaneity of performances.

\section{Jack Beatty}

The World According to Drucker, p. 30 